\title{
Small bottles - huge problem? A new phase of Poland's ongoing alcohol epidemic
}

\author{
Witold A. Zatoński ${ }^{1,2}$, Iwona Młoźniak ${ }^{1,3}$, Mateusz Zatoński1 ${ }^{1,2,4}$, Łukasz Gruszczyński ${ }^{5,6}$ \\ ${ }^{1}$ Health Promotion Foundation, Nadarzyn, Poland \\ 2European Observatory of Health Inequalities, the President Stanisław Wojciechowski State University of Applied Sciences \\ in Kalisz, Poland \\ ${ }^{3}$ Józef Piłsudski University of Physical Education in Warsaw, Poland \\ ${ }_{4}^{4}$ Tobacco Control Research Group, Department for Health, University of Bath, Bath, UK \\ Institute of Law Studies of the Polish Academy of Sciences, Warsaw, Poland \\ ${ }^{6}$ Hungarian Academy of Sciences Centre for Social Sciences Institute for Legal Studies, Budapest, Hungary
}

\begin{abstract}
Alcohol consumption remains the leading cause of morbidity and premature mortality of young and middle-aged adults in Poland. Both vodka and beer consumption levels have increased in Poland in the last 15 years due to alcohol tax decreases and lax marketing laws. In 2008 the Polish spirits industry began promoting a new format of vodka drinking - small vodka bottles (SVBs). This article outlines the rapidly growing popularity of SVBs and their impact on alcohol consumption patterns in Poland. It also suggests some reasons underlying the growth of the SVB market, including easy availability, wide range of choices, convenience, and low prices. It concludes with a call for independent research that could help better understand, and effectively address, this new phase of Poland's alcohol epidemic.
\end{abstract}

KEY WORDS: vodka, spirits, alcohol control, life expectancy, commercial determinants of health.

ADDRESS FOR CORRESPONDENCE: Prof. Witold A. Zatoński, Health Promotion Foundation, 51 Mszczonowska St., 05-830 Nadarzyn, Poland, phone: +48 2237800 22, e-mail: wazatonski@promocjazdrowia.pl

Alcohol consumption is, alongside tobacco smoking, the leading cause of morbidity and premature mortality of young and middle-aged adults (20-64-year-olds) in Poland. As much as $25 \%$ of premature deaths in Poland are alcohol related [1-14]. Both these factors are crucial in understanding why premature mortality in this age group in Poland is so high, at around 100,000 deaths per year. The percentage of deaths before the age of 65 years in Poland is among the highest in Europe, and over twice as higher as in Western Europe (see slides 33 and 34 in Webappendix 2 in the "One hundred years of health in Poland" presentation) [6].

Alcohol consumption in Poland has rapidly increased since the beginning of the $21^{\text {st }}$ century. This trend followed the decision of the Polish government to cut the excise duty on spirits by $30 \%$ in 2002 (Fig. 1) [15-17]. In the years 2003-2008 annual vodka consumption rates doubled from 1.7 litres of pure alcohol per capita to
3.4 litres. In 2001 the rules on beer advertising have also been loosened (beer could be advertised on television from 8 p.m.) [17-19]. This might have contributed to the rapid increase in beer consumption, from 3.7 litres of pure alcohol per capita in 2000 to 5.2 litres in 2008 . Poland, traditionally a country with one of the highest levels of vodka consumption in Europe, also became one of the countries with the highest beer consumption, trailing only Czechia, Austria, and Germany. In 1989 annual beer consumption in Poland stood at 30 litres per capita, and in 2016 it was about 100 litres [10].

In the years 2008-2009 the spirits industry began implementing a new business strategy and promoting small vodka bottles (SVBs) - $100 \mathrm{ml}$ or $200 \mathrm{ml}$ capacity, usually flavoured $[20,21]$. A report published by the research company Synergion in May 2019 estimated that more than 1 billion SVBs are sold every year [20]. Moreover, the sale of SVBs increased by almost 10\% in 2018 . 

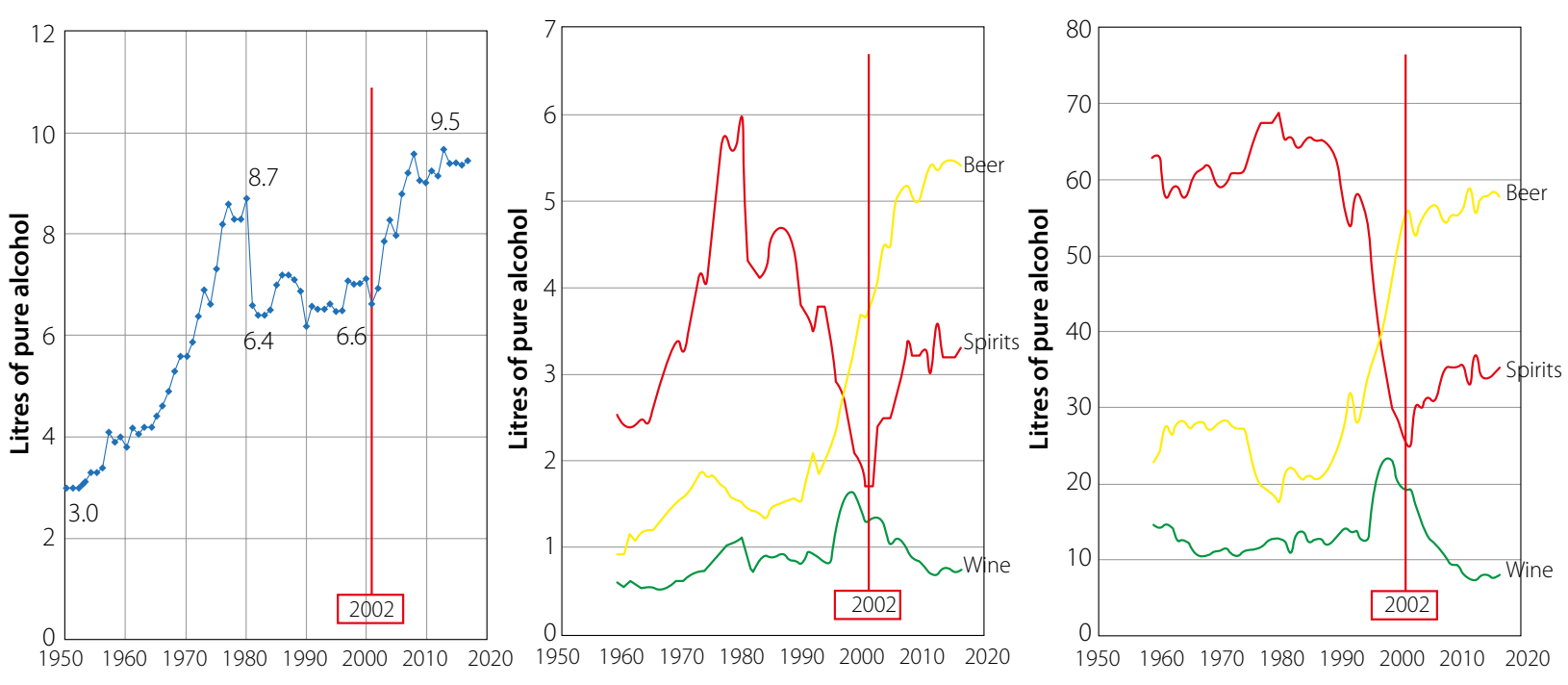

Source: Central Statistical Office and The State Agency for the Prevention of Alcohol-Related Problems (PARPA)

FIG. 1. Recorded per capita (0+) alcohol consumption in Poland (in litres of pure alcohol - 100\% spirit), 1950-2017

Currently, SVBs account for $17 \%$ of the entire vodka segment. Over half of all Poles drink SVBs once a month or more often, $54 \%$ of their consumers are women and $46 \%$ are men. In 2018, 3 million SVBs were sold each day. According to the Synergion report, $28 \%$ of SVBs are sold between 6 a.m. and 12 a.m. SVBs are equally popular in all socioeconomic categories [20,21].

The growing popularity of SVBs may be the result of a combination of easy availability, wide variety of flavours catering to a range of tastes (in 2017 there were 46 varieties), convenience, and their discrete character. SVBs can be consumed easily and quickly. Their prices are extremely low (vodka costs around $5 \mathrm{zł} / € 1.15$ per $100 \mathrm{ml})[14,20]$.

There is some indication that these changes have been altering the pattern of alcohol consumption in Poland, which seems to be changing from weekend binges to a new style of daily drinking. This consumption pattern may result in a state of continuous alcohol exhilaration, while drinkers may not exceed the legal limit of sobriety.

The phenomenon of SVBs has attracted much media interest but little research from public health experts. The lack of reliable data makes it impossible to draw conclusions on the actual scale of the phenomenon. The Synergion data have been disputed in the media by the Polish vodka industry, which argues that the numbers are exaggerated. However, no independent research exists which could help verify any of those claims [20,25].

Interdisciplinary research, involving epidemiologists, economists, sociologists, and other scholars, is urgently needed to gauge the social and commercial underpinnings of this emerging alcohol problem, and its implications for public health. Its results should motivate much-needed political and regulatory actions. This is particularly urgent given that epidemiological analyses indicate that the observed stalling and than the freezing of the health improvement in Poland in recent years is most likely related to the increase in alcohol consumption (see as well Zatoński W. One hundred years of health in Poland on pages 11-19; Zdrojewski T. Completing the cardiovascular revolution: smoking, alcohol, diet, and air pollution on page 38; Moskalewicz J. Evolution of alcohol policy in Poland during the transition period on page 41) $[12,22-28]$. Finally, it is crucial in mitigating the health consequences of the new strategies of the alcohol industry, which in recent years has been trialling selling spirits in even smaller containers, such as $40 \mathrm{ml}$ plastic shot glasses sold in retail stores for about 2 zł/€0.45 [29].

\section{ACKNOWLEDGEMENTS}

Authors would like to thank Katarzyna Rosik and Kinga Janik-Koncewicz for their valuable help in preparing the article.

\section{DISCLOSURE}

The authors report no conflict of interest.

\section{References}

1. Bagnardi V, Zatonski W, Scotti L, et al. Does drinking pattern modify the effect of alcohol on the risk of coronary heart disease? Evidence from a meta-analysis. J Epidemiol Community Health 2008; 62: 615-619.

2. GBD 2016 Alcohol Collaborators. Alcohol use and burden for 195 countries and territories, 1990-2016: a systematic analysis for the Global Burden of Disease Study 2016. Lancet 2018; 392: 1015-1035.

3. Global status report on alcohol and health 2018. WHO 2018. Available from: https://www.who.int/substance_abuse/publications/global_alcohol_report/en/ (accessed: 18 June 2019). 
4. Mackenbach JP, Kulhanova I, Bopp M, et al. Inequalities in alcohol-related mortality in 17 European countries: a retrospective analysis of mortality registers. PLoS Med 2015; 12 e1001909.

5. Janik-Koncewicz K, Herbeć A, Zatoński M, et al. Building health literacy in a Polish region: protocol for the POWER project in Lower Silesia. J Health Inequal 2018; 4: 27-30.

6. Lachenmeier DW, Ganss S, Rychlak B, et al. Association between quality of cheap and unrecorded alcohol products and public health consequences in Poland. Alcohol Clin Exp Res 2009; 33: 1757-1769.

7. Rehm J, Sulkowska U, Mańczuk M, et al. Alcohol accounts for a high proportion of premature mortality in central and eastern Europe. Int J Epidemiol 2007; 36: 458-467.

8. Schuz J, Espina C, Villain P, et al., Working Groups of Scientific Experts. European Code against Cancer $4^{\text {th }}$ Edition: 12 ways to reduce your cancer risk. Cancer Epidemiol 2015; 39 (Suppl 1): 1-10.

9. Świątkiewicz G, Wieczorek $€$, Allamani A. What influences changes in alcoholic beverage consumption over time? Poland in the light of the European Union Amphora Study. Substance Use \& Misuse 2014; 49: 1601-1610.

10. Wojtyniak B, Goryński P (eds.). Health status of Polish population and its determinants. National Institute of Public Health - National Institute of Hygiene, Warsaw 2018.

11. Zatoński W and the HEM project team. Closing the health gap in European Union. Cancer Center and Institute of Oncology, Warsaw 2008

12. Zatoński W, Sulkowska U, Zatoński M, Herbeć A, Muszyńska M. Alcohol taxation and premature mortality in Europe. Lancet 2015; 385: 1181.

13. Zatoński WA, Sulkowska U, Mańczuk M, et al. Liver cirrhosis mortality in Europe, with special attention to Central and Eastern Europe. Eur Addict Res 2010; 16: 193-201.

14. Nielsen. Aktualny obraz rynku alkoholowego w Polsce. Available from: https://www.nielsen.com/pl/pl/insights/report/2018/ alcoholic-beverages-in-poland/ (accessed: 18 June 2019).

15. Ordinance of the Minister of Finance of 01.08.2002, no. 1065. Available from: http://prawo.sejm.gov.pl/isap.nsf/DocDetails. xsp?id=WDU20021251065 (accessed: 18 June 2019).

16. Przewoźniak K, Łobaszewski J, Wojtyła A, et al. Alcohol drinking patterns and habits among a sample of PONS study subjects: preliminary assessment. Ann Agric Environ Med 2011; 18: 221-228.

17. Popova S, Rehm J, Patra J, Zatoński W. Comparing alcohol consumption in central and eastern Europe to other European countries. Alcohol Alcohol 2007; 42: 465-473.

18. Rehm J, Zatoński W, Taylor B, Anderson P. Epidemiology and alcohol policy in Europe. Addiction 2011; 106 (Suppl 1): 11-19.

19. Act of 27 April 2001 regarding Upbringing in Sobriety and Countering Alcoholism, the Broadcasting Act, and the Stamp Duty Act. Available from: http://www.parpa.pl/download/ustawaang.pdf (accessed: 18 June 2019).

20. Synergion. Where is the little vodka flowing? Report on the little vodka' market and the changes it causes in consumer behaviour. Available from: https://www.slideshare.net/synergion/ synergion-raport-dokad-plynie-mala-wodka-2019 (accessed: 18 June 2019).

21. Sprzedaż wódek w sklepach małoformatowych. Available from: http://www.cmr.com.pl/sprzedaz-wodek-w-sklepach-maloformatowych/ (accessed: 18 June 2019).

22. Rehm J, Probst C. Decreases of life expectancy despite decreases in non-communicable disease mortality: the role of substance use and socioeconomic status. Eur Addict Res 2018; 24: 53-59.

23. Rehm J, Stelemekas M, Badaras R. Research protocol to evaluate the effects of alcohol policy changes in Lithuania. Alcohol Alcohol 2019; 54: 112-118.

24. Zatoński M, Herbeć A. Are mass media campaigns effective in reducing drinking and driving? Systematic review - an update. J Health Inequal 2016; 2: 52-60.

25. Woźniak B. Not all shot glasses are equal, or Synergion versus ZPPPS Available from: http://www.portalspozywczy.pl/alkohole-uzywki/wiadomosci/malpka-malpce-nie-rowna-czylisynergion-kontra-zp-pps,170279.html (accessed: 18 June 2019).

26. Stokłosa M, Drope J, Zatoński M, Zatoński WA. Towards improved public health: Affecting alcohol and tobacco affordability and consumption in Poland through taxation. J Health Inequal 2016; 2: 101-104.

27. Zatoński W. Alcohol and health: what is good for the French may not be for the Russians. J Epidemiol Community Health 1998; 52: 766-767.

28. Janik-Koncewicz K, Ritchie D, Blicharz U, Zatoński WA. Towards systematic evaluation of the European Code Against Cancer. Dissemination of the Code in Poland. J Health Inequal 2017; 3: 162-166

29. Fal M, Brzózka K. Ekspert o sprzedaży wódki w kieliszkach: To przemyślana strategia. Hodują sobie przyszłych użytkowników. Gazeta.pl. Available from: http://wiadomosci.gazeta.pl/ wiadomosci/1,114871,18147523,Ekspert_o_sprzedazy_wodki_w_kieliszkach_To_przemyslana.html (accessed: 18 June 2019).

\section{AUTHOR'S CONTRIBUTIONS}

WAZ prepared the concept of the article. IM, MZ and $Ł G$ prepared the draft version. All authors contributed to preparing final text of the publication. 